\title{
ISONIAZID INTRAPERITONEAL DOSE CHARACTERISTICS IN WHITE MICE WITH INDUCED LIVER FIBROSIS
}

\author{
Triyanta Yuli Pramana,,2) , Brian Wasita3), Ambar Mudigdo3), \\ Suroto ${ }^{4}$, Bambang Poerwanto ${ }^{5}$ \\ 1)Medical Science Program, Universitas Sebelas Maret. \\ 2)Division of Gastroenterology and Hepatology, Department of Internal Medicine, \\ Dr Moewardi Hospital Surakarta. \\ 3)Department of Pathology Anatomy, Dr Moewardi Hospital Surakarta. \\ 4)Department of Neurology, Dr Moewardi Hospital Surakarta. \\ 5)Department of Internal Medicine, Dr Moewardi Hospital Surakarta.
}

\begin{abstract}
Background: Isoniazid (INH) is the main drug of choice for tuberculosis. It can be administered singly or in combination with other anti-tuberculosis agents. However, long-term INH therapy may increase the risk of liver toxicity. Previous studies reported that high dose of INH for 1 week can result in steatosis and an increase in sorbitol dehydrogenase (SDH) that indicates mitochondrial damage. Long term use of low dose INH did not induce steatosis in rat liver. This study aimed to determine the INH intraperitoneal dose characteristics in white mice with induced liver fibrosis.

Subjects and Method: This was a randomized controlled trial. A sample of 32 white male mice was selected for this study, and was randomly assigned to 4 groups: (1) INH intraperitoneal $50 \mathrm{mg} / \mathrm{kg} \mathrm{BW} /$ day; (2) $60 \mathrm{mg} / \mathrm{kg} \mathrm{BW} /$ day; (3) $70 \mathrm{mg} / \mathrm{kg} \mathrm{BW} /$ day; (4) $80 \mathrm{mg} / \mathrm{kg} \mathrm{BW} /$ day. Each group consists of 2 mice. The treatment was given for 2 weeks, 3 weeks, 4 weeks and 5 weeks. After treatment, mice were sacrificed. Liver tissue was taken and histopathological preparations were made by painting with hematoxylineosin for assessment of damage. The independent variable was INH injected intraperitoneally. The dependent variables were hepatocyte ballooning, steatosis, ductular reaction, activity score, and fibrosis. The data were analyzed by paired $t$ test.

Results: High intraperitoneal INH dose (80 mg / kg BW / day) and long treatment duration ( 5 weeks) were associated with liver damage. Liver tissue in rats in this group showed hepatocyte ballooning prominence ( $2^{\text {nd }}$ degree), steatosis ( $3^{\text {rd }}$ degree), and ductus reaction ( $2^{\text {nd }}$ degree). In addition, liver tissue in rats in that group also showed severe fibrosis (many links or septa fibrous tissue).
\end{abstract}

Conclusion: High intraperitoneal INH dose (8o mg / kg BW / day) and long treatment duration (5 weeks) are associated with liver damage.

Keywords: intraperitoneal INH, dosage characterization, liver injury

\section{Correspondence:}

Triyanta Yuli Pramana. Study Program in Medical Sciences, Universitas Sebelas Maret, Surakarta, Central Java. Email: typramana@gmail.com. Mobile: o81338327327.

The $6^{\text {th }}$ International Conference on Public Health Best Western Premier Hotel, Solo, Indonesia, October 23-24, 2019 | 352 